\title{
Article
}

\section{Replacement of Natural Sand with Expanded Vermiculite in Fly Ash-Based Geopolymer Mortars}

\author{
Osman Gencel ${ }^{1, *}$, Aliakbar Gholampour ${ }^{2}$, Hayrettin Tokay ${ }^{3}$ and Togay Ozbakkaloglu ${ }^{4, *}$ (D) \\ 1 Civil Engineering Department, Bartin University, 74100 Bartin, Turkey \\ 2 College of Science and Engineering, Flinders University, Tonsley, SA 5042, Australia; \\ aliakbar.gholampour@flinders.edu.au \\ 3 Bartin Provincial Directorate of Environment and Urbanism, 74100 Bartin, Turkey; \\ hayrettin.tokay@hotmail.com \\ 4 Ingram School of Engineering, Texas State University, San Marcos, TX 78666, USA \\ * Correspondence: ogencel@bartin.edu.tr (O.G.); togay.oz@txstate.edu (T.O.)
}

Citation: Gencel, O.; Gholampour, A.; Tokay, H.; Ozbakkaloglu, T.

Replacement of Natural Sand with Expanded Vermiculite in Fly Ash-Based Geopolymer Mortars. Appl. Sci. 2021, 11, 1917. https:// doi.org/10.3390/app11041917

Academic Editor: Joan Formosa Mitjans

Received: 2 February 2021

Accepted: 17 February 2021

Published: 22 February 2021

Publisher's Note: MDPI stays neutral with regard to jurisdictional claims in published maps and institutional affiliations.

Copyright: (c) 2021 by the authors. Licensee MDPI, Basel, Switzerland. This article is an open access article distributed under the terms and conditions of the Creative Commons Attribution (CC BY) license (https:// creativecommons.org/licenses/by/ $4.0 /)$.

\begin{abstract}
Increasing the thermal insulation of building components to reduce the thermal energy loss of buildings has received significant attention. Owing to its porous structure, using expanded vermiculite as an alternative to natural river sand in the development of building materials would result in improvement of the thermal performance of buildings. This study investigates the properties of fly ash (FA)-based geopolymer mortars prepared with expanded vermiculite. The main aim of this study was to produce geopolymer mortar with lower thermal conductivity than conventional mortar for thermal insulation applications in buildings. A total of twelve batches of geopolymers were prepared for evaluating their different properties. The obtained results show that, at a given FA and expanded vermiculite content, the geopolymers prepared with a 10 molar $\mathrm{NaOH}$ solution exhibited a higher flowability, water absorption and porosity, as well as a lower dry unit weight, compressive strength, ultrasound pulse velocity and thermal conductivity compared with those prepared with a 15 molar $\mathrm{NaOH}$ solution. As is also shown, the geopolymers containing expanded vermiculite $(15 \%)$ developed a lower flowability $(\sim 6 \%)$, dry unit weight $(\sim 6 \%)$, compressive strength $(\sim 7 \%)$, ultrasound pulse velocity $(\sim 6 \%)$ and thermal conductivity $(\sim 18 \%)$, as well as a higher apparent porosity $(\sim 6 \%)$ and water absorption $(\sim 9 \%)$ compared with those without expanded vermiculite at a given FA content and $\mathrm{NaOH}$ concentration. The findings of this study suggest that incorporating expanded vermiculite in FA-based geopolymer mortar can provide eco-friendly and lightweight building composites with improved sound and thermal insulation properties, contributing toward the reduction of the environmental effects of waste materials and conservation of natural sand.
\end{abstract}

Keywords: expanded vermiculite; geopolymer; fly ash; strength; thermal conductivity; ultrasound pulse velocity

\section{Introduction}

As the most widely used construction material, concrete mainly consists of binder and natural aggregates. Ordinary Portland cement (OPC) is extensively used as a binder material in concrete production [1]. However, the cement industry contributes to 5-8\% of carbon dioxide emissions [2]. In addition, it is estimated that production of one ton of OPC results in about one ton of carbon dioxide being released into the atmosphere, causing a destructive impact on the environment [3]. In the meantime, natural river sand has been widely used as the fine aggregate component of concrete, which led to overexploitation of this non-renewable natural resource. As was reported previously [4], the overexploitation of natural river sand results in a negative environmental impact on the ecosystem. As a result, finding suitable alternatives for replacing OPC and natural sand in concrete production is important. 
Geopolymers, as alkali-activated aluminosilicate materials, are an environmentally friendly building and construction material [5]. In a geopolymer, an aluminosilicate binder is used as a replacement material for OPC [6]. Fly ash (FA) is an industrial byproduct which contains high-aluminosilicate resources [6]. As was reported previously, the annual generation of FA is about 750 million tons [7], but only $25 \%$ of it is currently being recycled [8]. Thus, there is great potential for FA to be used as an OPC alternative in concrete production, with the aim of reducing the negative impact of OPC and FA on the environment.

Vermiculate, as a naturally occurring mineral, is a hydrous phyllosilicate mineral [9]. It was reported that the worldwide production of vermiculite is approximately 2.35 million tons annually, with the main deposits being in South Africa, the United States, Australia, China, Russia, India and Uganda [10]. When vermiculite is heated to temperatures of $650-1000{ }^{\circ} \mathrm{C}$, it expands to up to 30 times its original volume. Therefore, vermiculite in its expanded form exhibits a very low density, high refractoriness, high sound absorption and low thermal conductivity [11,12]. Koksal et al. [13] reported that dehydration of vermiculite occurs at about $100{ }^{\circ} \mathrm{C}$, which is due to the weight loss of the physically absorbed water. Mass losses between $500{ }^{\circ} \mathrm{C}$ and $900{ }^{\circ} \mathrm{C}$ may be as a result of the loss of chemically absorbed water. As was reported by the United States Environmental Protection Agency (EPA) [14], the primary pollutants in the vermiculite expansion process are particulate matter (PM) and PM of less than 10 micrometers, and there is no data on carbon dioxide emissions corresponding to the vermiculite expansion process. Due to its excellent properties, expanded vermiculite has great potential to be used as an aggregate for producing lightweight concrete with excellent thermal and sound insulation characteristics. Sodium hydroxide and sodium silicate are two alkaline activators usually used in the production of geopolymers [5]. In the production of sodium hydroxide and sodium silicate, the required heat is about $300{ }^{\circ} \mathrm{C}$ for sodium hydroxide [15] and $1400{ }^{\circ} \mathrm{C}$ for sodium silicate [16], which are both lower compared with the heat required for cement production $\left(\sim 1500^{\circ} \mathrm{C}\right)$. In addition, the usage ratio of sodium silicate is about $0.5-2 \%$, which is significantly lower compared with that of sodium hydroxide and cement [5]. Therefore, production of sodium hydroxide and sodium silicate needs less energy than production of cement.

Many studies exist on cementitious materials containing lightweight aggregates, such as pumice, expanded polystyrene, perlite and expanded clay [12,17-21]. However, there are very few studies on the use of expanded vermiculite in cementitious materials $[9,12,22-31]$. Mladenovic et al. [27] studied the alkali-silica reactivity behavior of lightweight cement mortar containing expanded vermiculite, perlite, expanded glass and expanded clay as fine aggregates. They reported that the mortar containing expanded glass and perlite exhibited high alkali-silica reactivity, whereas those containing expanded vermiculite and expanded clay did not show any potential reactivity [27]. Schackow et al. [12] investigated the mechanical and thermal characteristics of cement mortar made with expanded vermiculite and expanded polystyrene as fine aggregates, and they reported that, at the same mortar volume ratio of $55 \%$, the mortar containing expanded vermiculite had a $25 \%$ higher 28 day compressive strength and $11 \%$ lower thermal conductivity compared with that containing expanded polystyrene. Koksal et al. [9,26] and Karatas et al. [24] assessed the influence of an elevated temperature on the mechanical behavior of cement mortar containing expanded vermiculite, and they revealed that mortar with a higher vermiculate content exhibited lower compressive and flexural strength losses at all temperature ranges up to $900{ }^{\circ} \mathrm{C}$. Shoukry et al. [30] used nano-metakaolin to improve the mechanical and microstructural characteristics of cement mortar with expanded vermiculite. They showed that incorporating 10\% nano-metakaolin (by weight of the vermiculite) led to about a $57 \%$ increase in the compressive and flexural strength and a $74 \%$ decrease in the capillary water absorption of the cement mortar [30]. It was shown by Won et al. [31] that incorporating $30 \%$ vermiculite as a fine aggregate in cement mortar resulted in a high thermal stability. Benli et al. [22] evaluated the effect of raw vermiculite and expanded 
vermiculite on the durability and mechanical characteristics of cement mortar at ambient and elevated temperatures, and they reported that mortar containing expanded vermiculite had better high-temperature resistance compared with that containing raw vermiculite. Sastri et al. [29] and Chandra Sekar et al. [23] assessed the influence of FA content on the compressive strength of cement mortar containing expanded vermiculite as a fine aggregate. They showed that the influence of FA content on the compressive strength of the mortar was lower with a larger content of vermiculite, in comparison with mortar with a smaller vermiculite content $[23,29]$.

Based on the above literature review, the existing studies on the addition of expanded vermiculate as a fine aggregate in cementitious materials focused on cement mortar, and no study has been performed on geopolymers. To address this research gap, this paper presents the first systematic study on different properties of FA-based geopolymers incorporating expanded vermiculate as a sand replacement material. The presented results show significant potential for using expanded vermiculite in geopolymers to improve their physical and thermal properties. This study not only contributes to achieving resource sustainability and cleaner production in the construction industry by reducing the use of natural river sand and cement, but it also presents a promising pathway for the development of eco-friendly construction materials based on industrial by-products and naturally occurring minerals that exhibit similar or better performance compared with conventional cement mortar.

\section{Experimental Program}

\subsection{Materials}

FA was obtained from Catalagzi Thermic santral in Zonguldak, Turkey and used as the binder. This FA had a specific surface area of $3450 \mathrm{~cm}^{2} / \mathrm{g}$ and a specific gravity of 2.2. Figure 1 shows the $X$-ray powder diffraction (XRD) analysis and scanning electron microscope (SEM) image of the FA. XRD was performed using monochromatic $\mathrm{Cu}-\mathrm{K} \alpha$ radiation at a scanning speed of $1.5^{\circ}(2 \theta) \mathrm{min}^{-1}$ in a conventional diffractometer (Rigaku SmartLab XRD) for mineralogical analysis. SEM was performed by a Tescan MAIA3 XMU to assess the morphology.

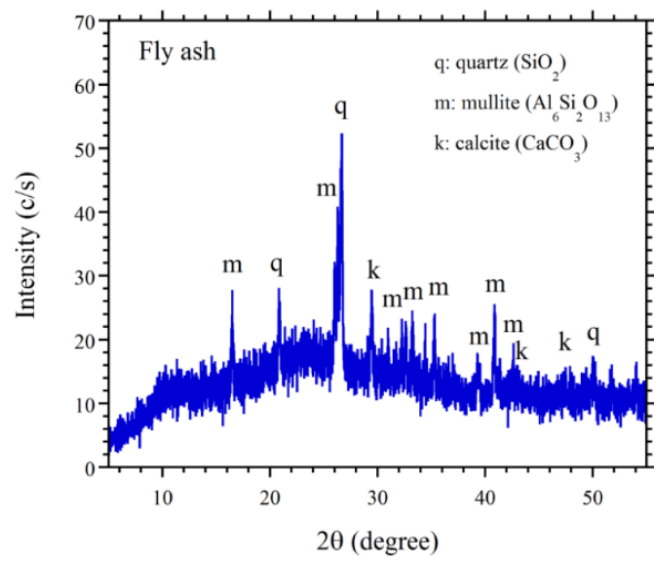

(a)

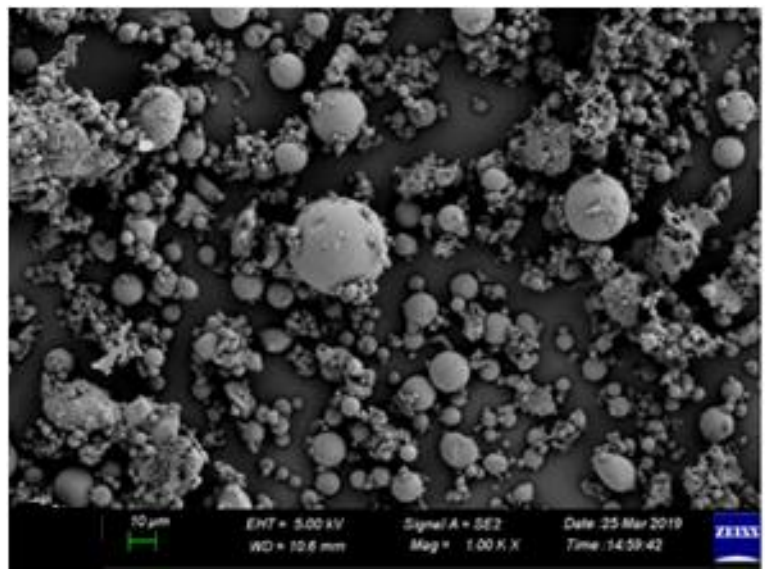

(b)

Figure 1. (a) X-ray powder diffraction (XRD) analysis and (b) scanning electron microscope (SEM) image of the fly ash (FA).

Natural sand as a fine aggregate material containing $97.8 \%$ silica was obtained from the Yazlar construction materials company in Bartin, Turkey. It had generally isometric and round particle shapes. The specific gravity and water absorption of the sand were $2.62 \%$ and $2.54 \%$, respectively. Expanded vermiculite as the sand replacement material was obtained from the territory of Sivas, Turkey, and it had maximum particle size of $4 \mathrm{~mm}$. Figure 2a illustrates the XRD analysis of the expanded vermiculite. The XRD analysis of 
the expanded vermiculite indicates that it mainly consisted of vermiculite, phlogopite and hydrobiotite. Figure $2 \mathrm{~b}$ represents the SEM image of the expanded vermiculite, showing its elongated accordion shape with an open, flaked texture.

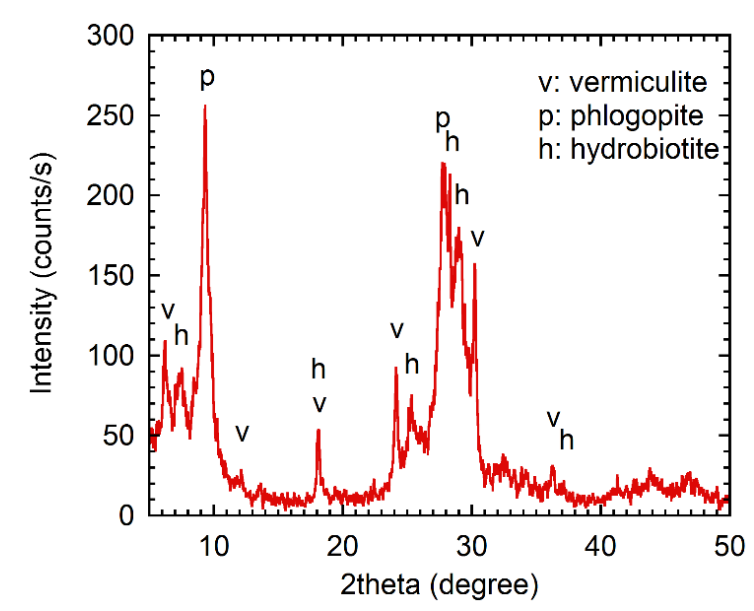

(a)

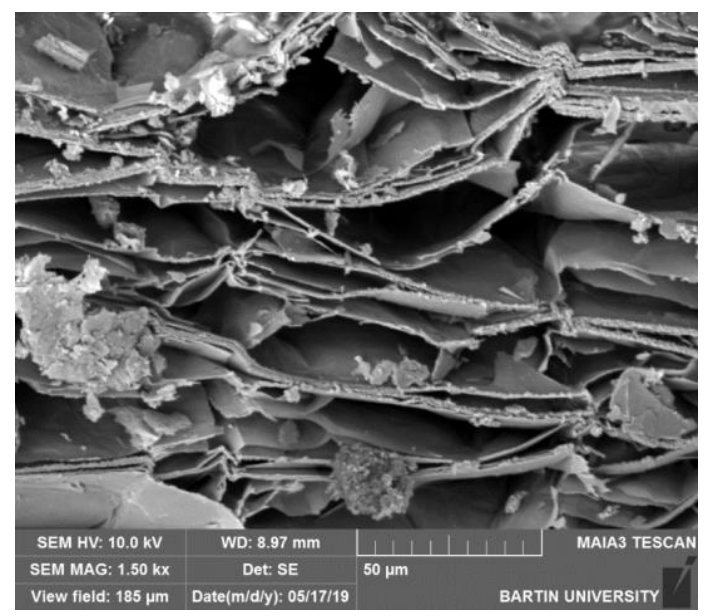

(b)

Figure 2. (a) XRD analysis and (b) SEM image of the expanded vermiculite.

Table 1 presents the chemical composition of FA and expanded vermiculite, and Table 2 shows the properties of the expanded vermiculite used in this study. The chemical compositions of the materials presented in the table were determined using X-ray fluorescence (XRF) (Spectro IQ II XRF spectrometer).

A combination of sodium hydroxide $(\mathrm{NaOH})$ and sodium silicate $\left(\mathrm{Na}_{2} \mathrm{SiO}_{3}\right)$ solutions with an $\mathrm{Na}_{2} \mathrm{SiO}_{3} / \mathrm{NaOH}$ ratio of 2 was used as the alkaline activator in the geopolymer mixes. These solutions were supplied by Dost Kimya in Istanbul, Turkey. Two NaOH concentrations of 10 and 15 molar were utilized in this study. $\mathrm{Na}_{2} \mathrm{SiO}_{3}$ utilized in this study had the properties shown in Table 3.

Table 1. Chemical compositions of FA and expanded vermiculite.

\begin{tabular}{ccc}
\hline Compounds & FA (\%) & Expanded Vermiculite (\%) \\
\hline $\mathrm{SiO}_{2}$ & 50.97 & 36.2 \\
$\mathrm{Al}_{2} \mathrm{O}_{3}$ & 27.2 & 18.2 \\
$\mathrm{Fe}_{2} \mathrm{O}_{3}$ & 4.11 & 12.1 \\
$\mathrm{CaO}$ & 10.56 & 3.7 \\
$\mathrm{MgO}$ & 1.82 & 17.1 \\
$\mathrm{Na} O$ & 0.30 & 0.2 \\
$\mathrm{~K}_{2} \mathrm{O}$ & 0.99 & 2.3 \\
$\mathrm{TiO}_{2}$ & 1.54 & 1.9 \\
$\mathrm{MnO}$ & 0.02 & - \\
$\mathrm{CuO}$ & 0.41 & - \\
$\mathrm{P}_{2} \mathrm{O}_{5}$ & 0.86 & - \\
$\mathrm{SO}_{3}$ & 0.22 & - \\
$\mathrm{LOI}$ & 0.51 & 8.1 \\
\hline
\end{tabular}


Table 2. Properties of the expanded vermiculite obtained from the supplier.

\begin{tabular}{cc}
\hline Color & Gold \\
\hline Shape & Accordion-shaped granule \\
Water capacity held & $240 \%$ (by weight) \\
Cation exchange capacity & $28 \%$ (by volume) \\
Thermal conductivity & $50-150 \mathrm{meg} / 100 \mathrm{~g}$ \\
Permeability & $0.065-0.062 \mathrm{~W} / \mathrm{mK}$ \\
pH & $95 \%$ \\
Sintering temperature & 8.1 \\
Combustibility & $650-1000{ }^{\circ} \mathrm{C}$ \\
Specific heat & Non-combustible \\
Specific gravity & $0.20-0.26 \mathrm{Kcal} / \mathrm{kg}^{\circ} \mathrm{C}$ \\
Bulk density & 0.22 \\
\end{tabular}

Table 3. Properties of $\mathrm{Na}_{2} \mathrm{SiO}_{3}$ obtained from the supplier.

\begin{tabular}{ccc}
\hline Parameter & Minimum & Maximum \\
\hline $\mathrm{SiO}_{2}(\%)$ & 26.5 & 31.5 \\
$\mathrm{Na}_{2} \mathrm{O}(\%)$ & 8.2 & 9.5 \\
Module $\left(\mathrm{SiO}_{2} / \mathrm{Na}_{2} \mathrm{O}\right)$ & 3.1 & 3.6 \\
Density $\left(20^{\circ} \mathrm{C}, \mathrm{g} / \mathrm{cm}^{3}\right)$ & 1.38 & 1.42 \\
Viscosity $\left(20^{\circ} \mathrm{C}, \mathrm{C}\right.$ poise $)$ & 300 & 1200 \\
\hline
\end{tabular}

\subsection{Mix Proportion, Production and Testing}

Twelve geopolymer mixtures were prepared, consisting of six mixtures with a 10 molar $\mathrm{NaOH}$ solution (group A) and six mixtures with a 15 molar $\mathrm{NaOH}$ solution (group B). In each group, sand was replaced with expanded vermiculite at two volume replacement ratios: $15 \%$ and $30 \%$. FA was used at volume ratios of $50 \%$ and $70 \%$ of the total mixture. The mix proportions were obtained based on the trial mixes. After preparing the trial mixes, it was observed that a content of expanded vermiculite in the mixture higher than $30 \%$ presented workability problems and a very low compressive strength. Therefore, the ratio of expanded vermiculite was limited to maximum of $30 \%$ in this study. Table 4 shows the mix proportions of different geopolymer mixes.

Table 4. Mix proportions of geopolymer mortar.

\begin{tabular}{|c|c|c|c|c|c|c|c|c|c|c|}
\hline Mix & $\begin{array}{c}\text { Water } \\
\left(\mathrm{kg} / \mathrm{m}^{3}\right)\end{array}$ & $\begin{array}{c}\mathrm{Na}_{2} \mathrm{SiO}_{3} \\
\left(\mathrm{~kg} / \mathrm{m}^{3}\right)\end{array}$ & $\begin{array}{c}\mathrm{NaOH} \\
\left(\mathrm{kg} / \mathrm{m}^{3}\right)\end{array}$ & $\begin{array}{c}\mathrm{NaOH} \\
\text { (Molar) }\end{array}$ & $\begin{array}{c}\text { Sand } \\
\left(\mathrm{kg} / \mathrm{m}^{3}\right)\end{array}$ & $\begin{array}{l}\text { Fly Ash } \\
\left(\mathrm{kg} / \mathrm{m}^{3}\right)\end{array}$ & $\begin{array}{l}\text { Vermiculite } \\
\left(\mathrm{kg} / \mathrm{m}^{3}\right)\end{array}$ & $\begin{array}{c}\text { Sand } \\
(\%)\end{array}$ & $\begin{array}{c}\text { Fly Ash } \\
(\%)\end{array}$ & $\begin{array}{c}\text { Vermiculite } \\
(\%)\end{array}$ \\
\hline S50F50V0A & 180 & 180 & 90 & 10 & 525 & 722 & 0 & 50 & 50 & 0 \\
\hline S35F50V15A & 180 & 180 & 90 & 10 & 367 & 722 & 10.2 & 35 & 50 & 15 \\
\hline S20F50V30A & 180 & 180 & 90 & 10 & 210 & 722 & 20.4 & 20 & 50 & 30 \\
\hline S30F70V0A & 220 & 180 & 90 & 10 & 295 & 946 & 0 & 30 & 70 & 0 \\
\hline S15F70V15A & 220 & 180 & 90 & 10 & 147 & 946 & 9.5 & 15 & 70 & 15 \\
\hline S0F70V30A & 220 & 180 & 90 & 10 & 0 & 946 & 19.1 & 0 & 70 & 30 \\
\hline S50F50V0B & 130 & 180 & 90 & 15 & 572 & 787 & 0 & 50 & 50 & 0 \\
\hline S35F50V15B & 110 & 180 & 90 & 15 & 412 & 811 & 11.4 & 35 & 50 & 15 \\
\hline S20F50V30B & 110 & 180 & 90 & 15 & 236 & 811 & 22.9 & 20 & 50 & 30 \\
\hline S30F70V0B & 210 & 180 & 90 & 15 & 302 & 971 & 0 & 30 & 70 & 0 \\
\hline S15F70V15B & 210 & 180 & 90 & 15 & 151 & 971 & 9.8 & 15 & 70 & 15 \\
\hline S0F70V30B & 185 & 180 & 90 & 15 & 0 & 1012 & 20.4 & 0 & 70 & 30 \\
\hline
\end{tabular}

For producing the geopolymer mixes, sand, FA and vermiculite were first mixed for $3 \mathrm{~min}$. Then, the pre-mixed alkaline activator and water were mixed with the dry components for $2 \mathrm{~min}$. Finally, the fresh mixture was poured into prism-shaped molds to produce $40 \times 40 \times 160 \mathrm{~mm}$ specimens. Different tests were conducted on each unique mix to assess the fresh and hardened properties of the geopolymer mixes, including the flowability, apparent porosity, dry unit weight, water absorption, compressive strength, 
ultrasound pulse velocity and thermal conductivity. The flowability test was performed according to EN 1015-3 [32]. The apparent porosity, unit weight and water absorption of the geopolymers were obtained from the prisms according to ASTM C20 [33]. The uniaxial compressive strength test was performed on half of the prisms based on TS EN 12390-3 [34], and the ultrasound test was performed on the prisms according to TS EN 12504-4 [35]. For measurement of the thermal conductivities of the prism specimens, a C-Therm Analyzer with a modified transient plane source was applied. Figure $3 \mathrm{a}-\mathrm{c}$ shows the performed tests for the compressive strength, ultrasound velocity and thermal conductivity of the geopolymers, respectively. Three nominally identical samples were used for each unique configuration. For evaluating the geopolymer microstructure, SEM analysis was performed on the specimen with 50\% FA and 30\% expanded vermiculite and prepared with a 10 molar $\mathrm{NaOH}$ solution.

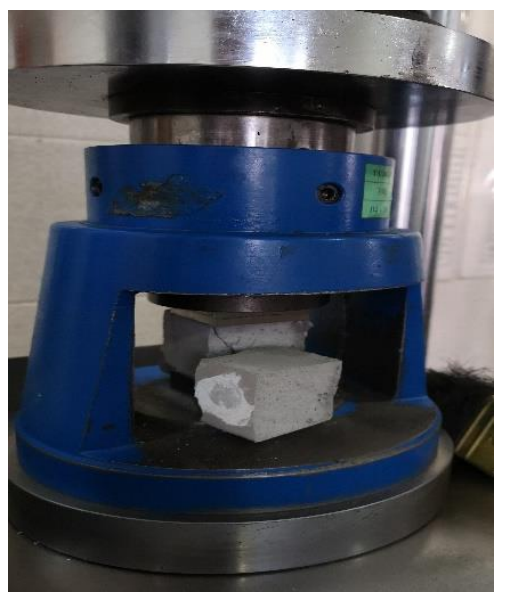

(a)

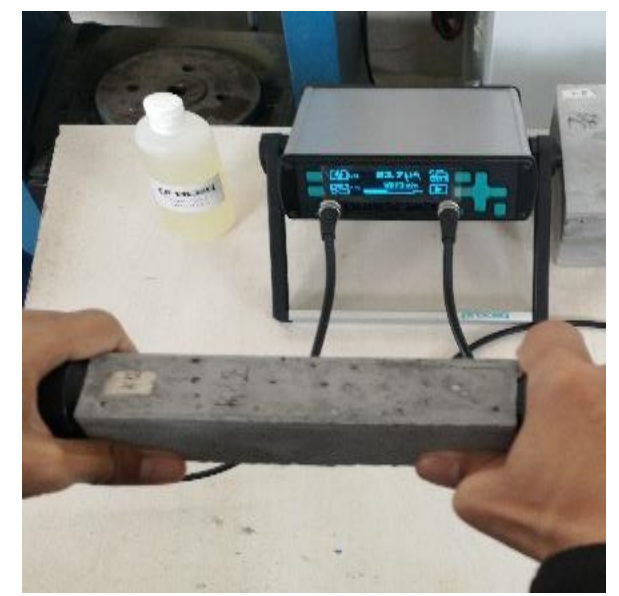

(b)

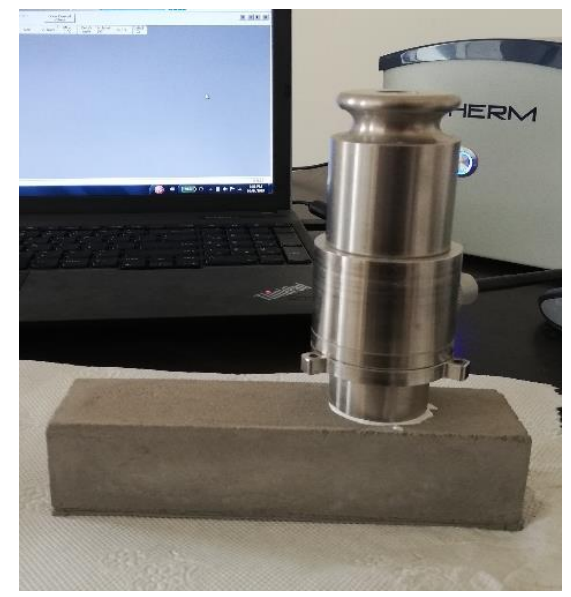

(c)

Figure 3. (a) Compression, (b) ultrasound and (c) thermal conductivity tests on geopolymer mortar.

The specimen labeling in Table 4 is as follows:

- $\quad$ Letters S, F and V stand for sand, FA and vermiculite, respectively;

- Letters A and B stand for geopolymer mixes with a 10 and 15 molar NaOH solution, respectively;

- The numbers after $\mathrm{S}, \mathrm{F}$ and $\mathrm{V}$ indicate the volume percentage of each material in the mixture.

For example, S35F50V15B is a geopolymer mix containing 35\% sand, 50\% FA and 15\% expanded vermiculite and prepared with a 15 molar $\mathrm{NaOH}$ solution.

\section{Results and Discussion}

\subsection{Flowability}

Figure 4 shows the flowability of different geopolymer mortar. As shown in the figure, the mixes with a 10 molar $\mathrm{NaOH}$ solution developed a larger flowability compared with those with a 15 molar $\mathrm{NaOH}$ solution. This observation agrees with previous studies on bottom ash-based geopolymer mortar [36] and FA-based geopolymer concrete [37-39], and this is due to the increase in the viscosity and leaching of the alumina and silica components of FA with increasing $\mathrm{NaOH}$ concentration, resulting in decreased flowability of the mixes [39]. The 10 molar $\mathrm{NaOH}$ mixes with $50 \%$ and $70 \%$ FA experienced $7-14 \%$ and $6-12 \%$ higher flowability than those companion mixes with a 15 molar $\mathrm{NaOH}$ solution, respectively. It can also be seen that, for a given vermiculite content and $\mathrm{NaOH}$ concentration, increasing the FA content caused increased flowability of the geopolymers. The higher flowabilities of the mixes with a higher FA content agree with previous studies on mortar [40-44] and concrete [45-47] and could be due to the morphology of FA, having a spherical particle shape and a smooth surface $[48,49]$. For the 10 molar $\mathrm{NaOH}$ solution, 
$70 \%$ FA mixes containing $0 \%, 10 \%$ and $30 \%$ vermiculite had $3 \%, 3 \%$ and $6 \%$ higher flowability, respectively, and for the 15 molar $\mathrm{NaOH}$ solution, they experienced $10 \%, 5 \%$ and $3 \%$ higher flowability than the companion $50 \%$ FA mixes, respectively.

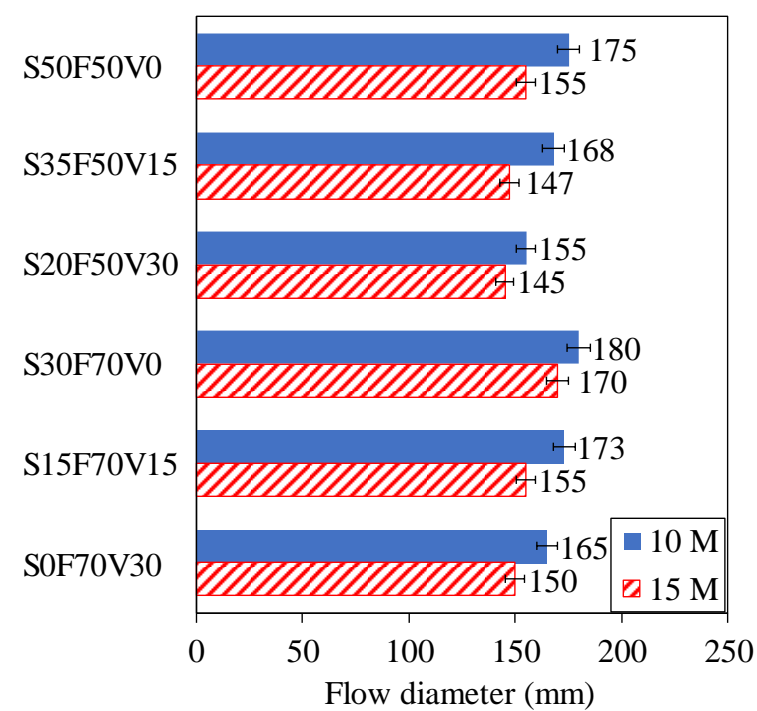

Figure 4. Flowability of geopolymer mortar.

As shown in Figure 4, incorporating expanded vermiculite led to decreased flowability of the mixes for a given FA content and $\mathrm{NaOH}$ concentration. It is also shown that an increase in the vermiculite content led to decreased flowability of the mixes. These behaviors agree with those reported in previous studies on conventional mortar [12] and could be due to the porous structure of expanded vermiculite, which absorbed the water of the fresh mixture. At $50 \% \mathrm{FA}$, the mixes containing $15 \%$ and $30 \%$ vermiculite had approximately $5 \%$ and $9 \%$ lower flowability, respectively, and at $70 \%$ FA, they had approximately $7 \%$ and $10 \%$ lower flowability compared with the companion mixes without vermiculite, respectively.

\subsection{Apparent Porosity}

The apparent porosities of the geopolymer mortar are shown in Figure 5. It is shown in the figure that, for a given $\mathrm{FA}$ and vermiculite content, the 10 molar $\mathrm{NaOH}$ mixes developed a higher apparent porosity in comparison with the 15 molar $\mathrm{NaOH}$ mixes. This agrees with previous studies on FA-based geopolymer mortar [50], FA-based geopolymer concrete [37] and geopolymers containing zeolitic tuff and marble waste [51]. This behavior was because of the higher microstructure compactness of the mixes having a higher activator concentration in comparison with those having a lower activator concentration [51]. The 10 molar $\mathrm{NaOH}$ mixes with $50 \%$ and $70 \%$ FA exhibited $2-7 \%$ and $4-10 \%$ higher apparent porosities in comparison with the 15 molar $\mathrm{NaOH}$ mixes, respectively. As is also shown in the figure, for a given vermiculite content and $\mathrm{NaOH}$ concentration, increasing the FA content resulted in the increased apparent porosity of the geopolymer mixes. This behavior matches with previous studies on concrete with recycled concrete fine aggregate [52] and gypsum composite [53,54], and it is due to the hollow structure of FA because of the cenosphere in its microstructure, causing increased porosity of the mix [55,56]. For the 10 molar $\mathrm{NaOH}$ solution, $70 \%$ FA mixes containing $0 \%, 10 \%$ and $30 \%$ vermiculite exhibited $13 \%, 12 \%$ and $17 \%$ higher porosities, respectively, and for the 15 molar $\mathrm{NaOH}$ solution, they exhibited $6 \%$, $10 \%$ and $14 \%$ higher porosities compared with the companion $50 \%$ FA mixes, respectively. 


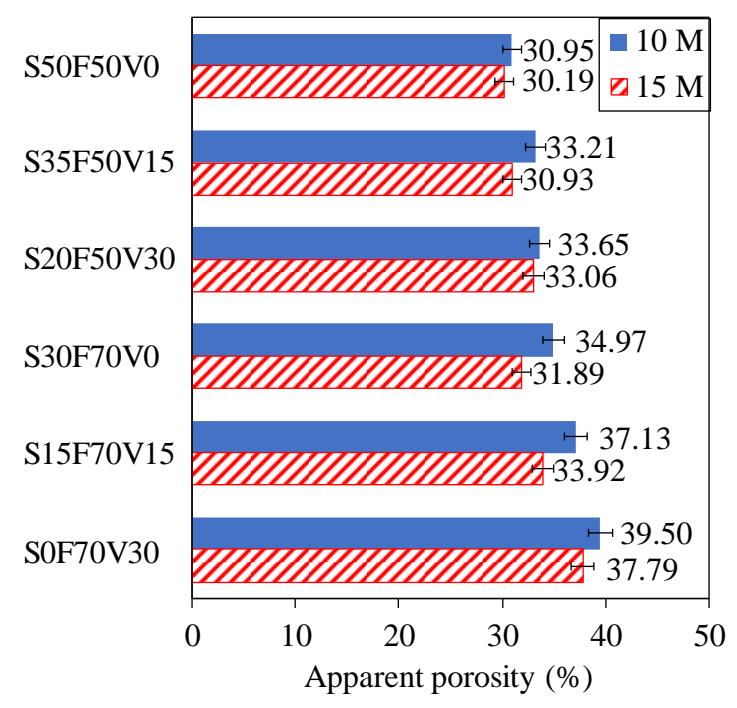

Figure 5. Apparent porosities of the geopolymer mortar.

It is shown in Figure 5 that, for a given FA content and $\mathrm{NaOH}$ concentration, replacing natural sand with expanded vermiculite caused increased apparent porosities in the mixes. It is also shown that increasing the vermiculite content caused increased porosities in the mixes. These behaviors are consistent with those reported in previous studies on conventional mortar [25,26], metakaolin-based geopolymer concrete [57] and clay-based bricks $[58,59]$. At 50\% FA, the mixes containing $15 \%$ and $30 \%$ vermiculite had approximately $5 \%$ and $9 \%$ higher porosities, respectively, and at $70 \%$ FA, they exhibited approximately $6 \%$ and $16 \%$ higher porosities in comparison with the companion mixes without vermiculite, respectively.

Figure 6 illustrates SEM images of fresh-cut surfaces of the S20F50V30A specimen. The lamellar-structured expanded vermiculite, which contained air between the vermiculite flakes, is visible in Figure 6a,b, and the FA particles are visible in Figure 6c. As can be seen in the figures, the mix with expanded vermiculite contained a large amount of porosities in its microstructure. In addition, the interfacial transition zone (ITZ) between the expanded vermiculite and the mortar mixture was porous, resulting in the weak bonding between the expanded vermiculite and the mortar mixture. These are the reason why geopolymer mixes containing larger expanded vermiculite contents exhibit higher porosities, leading to a lower dry unit weight, compressive strength, ultrasound pulse velocity and thermal conductivity, as well as more water absorption, as will be discussed in the following sections.

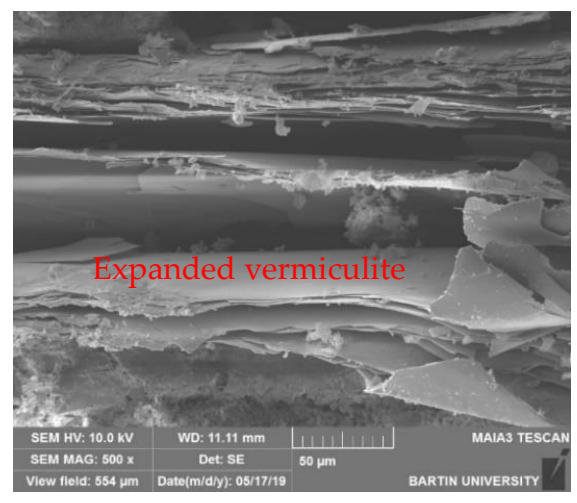

(a)

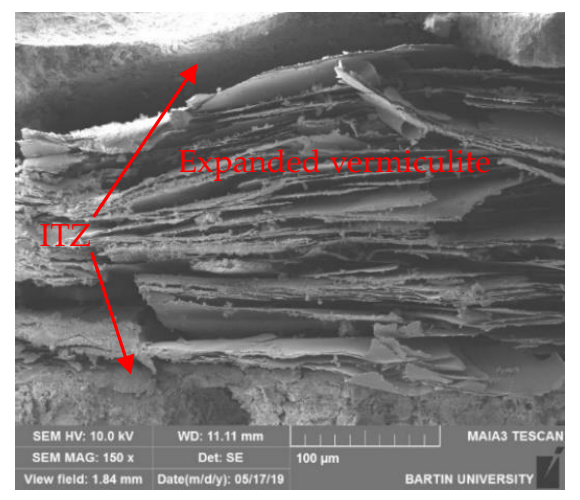

(b)

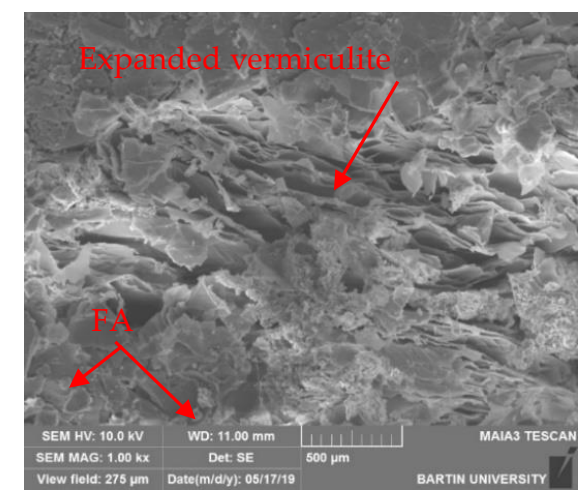

(c)

Figure 6. $(\mathbf{a}-\mathbf{c})$ SEM images of fresh-cut surfaces of the S20F50V30A specimen with different magnifications. 


\subsection{Dry Unit Weight}

The test results of the dry unit weights of the geopolymer mixes are shown in Figure 7. As can be observed from the figure, the mixes with a 10 molar $\mathrm{NaOH}$ solution developed lower unit weights in comparison with those prepared with a 15 molar $\mathrm{NaOH}$ solution. The lower unit weight of the mixes having lower activator concentrations agrees with previous research on FA-based geopolymer mortar [50], FA-based geopolymer concrete [60] and geopolymers having zeolitic tuff and marble waste [51,61], and this was because the densification between the particles of the mixes increased with the increasing activator concentration [50]. The 10 molar $\mathrm{NaOH}$ mixes with $50 \%$ and $70 \%$ FA had $4-11 \%$ and $8-14 \%$ lower unit weights compared with the companion mixes with 15 molar $\mathrm{NaOH}$ solution, respectively. For a given vermiculite content and $\mathrm{NaOH}$ concentration, increasing the FA content resulted in a decreased unit weight of the geopolymers. The lower unit weight of the mixes with a higher content of FA agrees with previous research on concrete with recycled concrete fine aggregate [52] and gypsum composite [53,54], and this was due to the less specific gravity of FA in comparison with that of sand, which was replaced with FA. For the 10 molar $\mathrm{NaOH}$ solution, the $70 \%$ FA mixes containing $0 \%, 10 \%$ and $30 \%$ vermiculite had $13 \%, 7 \%$ and $10 \%$ lower unit weights, respectively, and for the 15 molar $\mathrm{NaOH}$ solution, they had $3 \%, 4 \%$ and $9 \%$ lower unit weights compared with the companion $50 \%$ FA mixes, respectively.

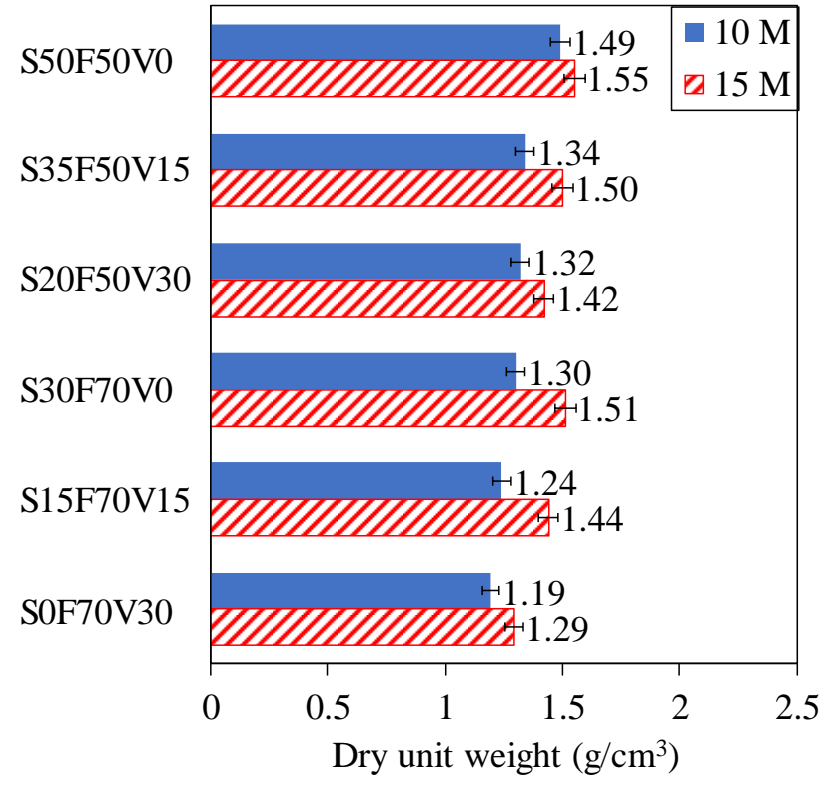

Figure 7. Dry unit weights of the geopolymer mortar.

As shown in Figure 7, the incorporation of expanded vermiculite led to a decrease in the unit weights of the mixes for a given FA content and $\mathrm{NaOH}$ concentration. It can also be seen that increasing the content of vermiculite caused a decrease in the unit weights of the mixes. These results agree with previous research on conventional mortar [12,25,26,28,62], conventional concretes [63,64], metakaolin-based geopolymer concrete [57], slag-based geopolymer mortar [65] and fibrous gypsum plasters [66], and they happened because of the lower specific gravity of expanded vermiculite in comparison with the sand [26]. This could also be due to the existence of voids in the structure of the expanded vermiculite, as was reported by Schachow et al. [12]. At 50\% FA, the mixes containing 15\% and 30\% vermiculite exhibited approximately $7 \%$ and $10 \%$ lower unit weights, respectively, and at $70 \% \mathrm{FA}$, they experienced approximately $5 \%$ and $12 \%$ lower unit weights than the companion mixes with $0 \%$ vermiculite, respectively. It was reported by Hossain et al. [19] that mortar mixes containing $100 \%$ expanded clay and pumice as the other types of lightweight materials exhibited dry unit weights of higher than $1800 \mathrm{~kg} / \mathrm{m}^{3}$. As was 
reported by Mo et al. [28], the dry unit weight of cement-based mortar containing 30\% expanded vermiculite was $1774 \mathrm{~kg} / \mathrm{m}^{3}$. However, the dry unit weights of the mortar of this study were less than $1500 \mathrm{~kg} / \mathrm{m}^{3}$ with up to $30 \%$ of expanded vermiculite, which is lower than the existing studies with clay, pumice and expanded vermiculite.

\subsection{Water Absorption}

The water absorption test results of the different mixes are presented in Figure 8. It is shown that, for a given FA and vermiculite content, the mixes prepared with a 10 molar $\mathrm{NaOH}$ solution developed higher water absorption compared with those prepared with a 15 molar $\mathrm{NaOH}$ solution. This observation matches with those of previous research on FA-based geopolymer concrete [37,67], FA and ground granulated blast furnace slagbased geopolymer mortar [68] and geopolymers containing marble waste and zeolitic tuff [51]. This behavior was due to the lower porosities of the mixes having larger activator concentrations in comparison with those having lower activator concentrations [51]. The 10 molar $\mathrm{NaOH}$ mixes with $50 \%$ and $70 \%$ FA exhibited $4-14 \%$ and $10-25 \%$ higher water absorptions than the 15 molar $\mathrm{NaOH}$ mixes, respectively. It is also shown that, for a given vermiculite content and $\mathrm{NaOH}$ concentration, the mixes with larger FA contents had higher water absorption than those with smaller FA contents. This agrees with previous studies on concrete with recycled concrete fine aggregate [52] and gypsum composite [53,54], and this is due to the increase in the microstructure porosity of mixes with increasing FA contents, leading to increased water absorption of the mixes [69]. At a 10 molar $\mathrm{NaOH}$ solution, $70 \%$ FA mixes containing $0 \%, 10 \%$ and $30 \%$ vermiculite exhibited $31 \%, 23 \%$ and $42 \%$ higher water absorption, respectively, and at a 15 molar $\mathrm{NaOH}$ solution, they exhibited $9 \%, 20 \%$ and $35 \%$ larger absorption in comparison with the companion $50 \%$ FA mixes, respectively.

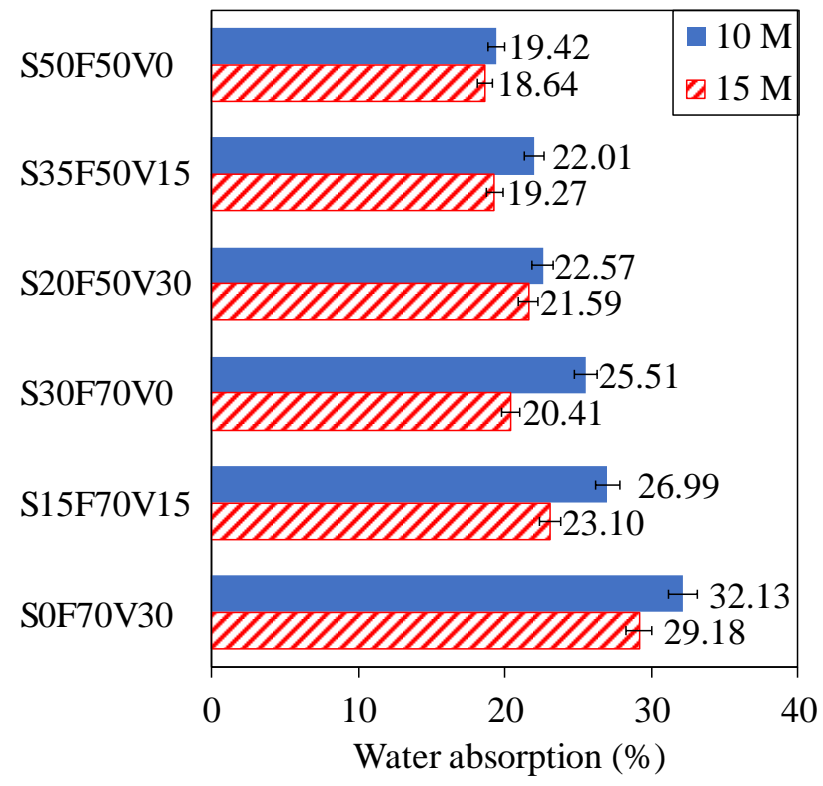

Figure 8. Water absorption of the geopolymer mortar at 28 days.

According to Figure 8, adding expanded vermiculite resulted in an increase in the water absorption of the mixes for a given FA content and $\mathrm{NaOH}$ concentration. As is also shown, the increased content of vermiculite caused an increase in the water absorption of the mixes. These findings are consistent with previous studies on conventional mortar $[12,25,26,62]$ and gypsum composites [58], and this happens because of the porous structure of the expanded vermiculite, as discussed in Section 3.2. At 50\% FA, the mixes containing $15 \%$ and $30 \%$ vermiculite exhibited approximately $8 \%$ and $16 \%$ higher water absorption, respectively, and at 70\% FA, they exhibited approximately $10 \%$ and $35 \%$ higher water absorption in comparison with the companion mixes without vermiculite, respectively. 


\subsection{Compressive Strength}

Figure 9 illustrates the 28-day compressive strength of the geopolymer mixes. According to the figure, the mixes with a 10 molar $\mathrm{NaOH}$ solution developed lower compressive strengths compared with those having a 15 molar $\mathrm{NaOH}$ solution. The higher compressive strength of geopolymers having a higher activator concentration agrees with previous research on bottom ash-based geopolymer mortar [36], FA-based geopolymer concrete $[37,38,60]$, geopolymer mortar containing rice husk ash [70] and geopolymers containing zeolitic tuff and marble waste [51], and this is because of the larger porosity of the mixes having lower activator concentrations [51]. The 10 molar $\mathrm{NaOH}$ mixes with $50 \%$ and $70 \%$ FA exhibited $13-19 \%$ and 18-22\% lower compressive strengths in comparison with the 15 molar $\mathrm{NaOH}$ mixes, respectively. As can be observed from Figure 9, for a given vermiculite content and $\mathrm{NaOH}$ concentration, an increase in the FA content caused a decrease in strength in the geopolymer mixes. The lower compressive strengths of the mixes with higher FA contents agree with previous studies on mortar [40-44] and concrete [45-47,52], and this is due to the non-hydraulic behavior of FA at ambient temperature. Therefore, the formation of geopolymer gel takes longer for a mix with a higher FA content $[47,71]$. For the 10 molar $\mathrm{NaOH}$ solution, $70 \%$ FA mixes containing $0 \%, 10 \%$ and $30 \%$ vermiculite experienced $10 \%, 13 \%$ and $20 \%$ lower compressive strengths, respectively, and for the 15 molar $\mathrm{NaOH}$ solution, they showed $4 \%, 9 \%$ and 19\% lower compressive strengths compared with the $50 \%$ FA mixes, respectively.

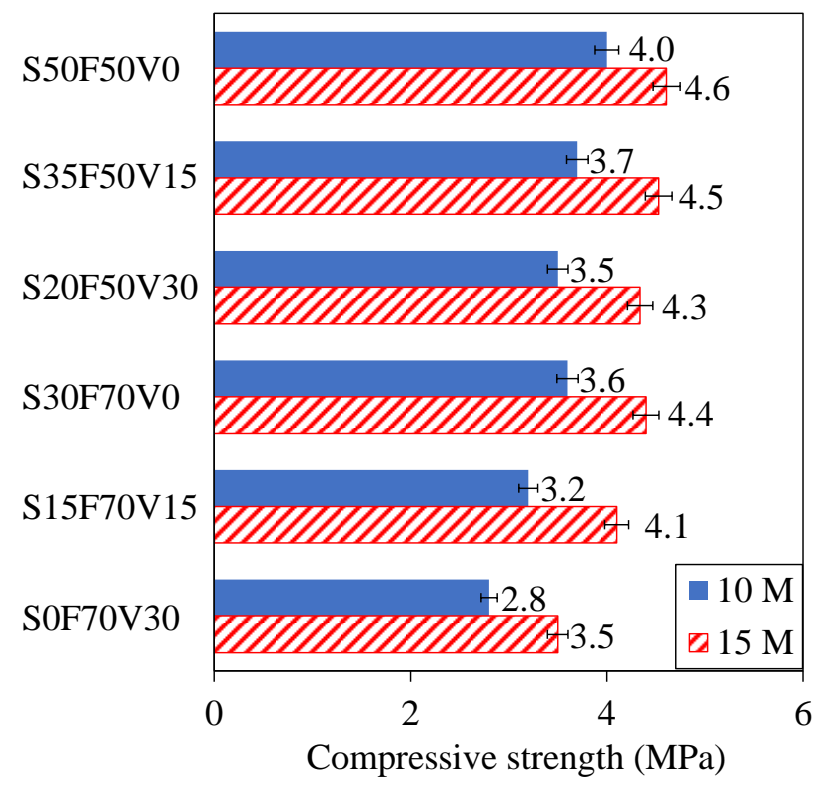

Figure 9. Compressive strengths of the geopolymer mortar at 28 days.

Based on Figure 9, incorporating expanded vermiculite led to a decrease in the compressive strengths of the mixes for a given FA content and $\mathrm{NaOH}$ concentration. As is also shown, an increase in the vermiculite content led to decreased strengths of the mixes. These behaviors agree with those reported in previous research on conventional mortar $[12,25,26]$, conventional concrete [63,64], metakaolin-based geopolymer concrete [57] and clay-based bricks $[58,59]$ and they happened because a higher vermiculate content in the mix required a larger water content for completing the hydration process, which in turn resulted in the strength of the mix [63]. At 50\% FA, the mixes containing $15 \%$ and $30 \%$ vermiculite had approximately $5 \%$ and $9 \%$ lower strengths, respectively, and at 70\% FA, they had approximately $9 \%$ and $21 \%$ lower strengths compared with the companion mixes without vermiculite, respectively. As can be observed in Figure 9, the compressive strengths of all the mixes met the minimum compressive strength of building panels by the EN 13279 standard (i.e., $2 \mathrm{MPa}$ ) [72]. 


\subsection{Ultrasound Pulse Velocity}

Figure 10 represents the ultrasound pulse velocities of different geopolymer mortar. It is illustrated in the figure that, for a given FA and vermiculite content, the mixes having a 10 molar $\mathrm{NaOH}$ solution exhibited lower ultrasound pulse velocities in comparison with those having a 15 molar $\mathrm{NaOH}$ solution. The obtained trend is consistent with that reported in previous studies on FA-based geopolymer mortar [70] and geopolymer mortar containing rice husk ash [70], and this is attributed to decreased porosities in the mixes with increasing activator concentrations, causing an increased ultrasound pulse velocity [51]. The 10 molar $\mathrm{NaOH}$ mixes with $50 \%$ and $70 \%$ FA experienced $3-7 \%$ and $3-11 \%$ lower ultrasound velocities compared with companion mixes having a 15 molar $\mathrm{NaOH}$ solution, respectively. As was also observed, for a given content of vermiculite and concentration of $\mathrm{NaOH}$, increasing the FA content caused decreased ultrasound velocities in the mixes. This behavior agrees with that found in previous studies on concrete [73,74], and it happens because of the increase in the porosities of the mixes with increasing contents of FA [73]. For the 10 molar $\mathrm{NaOH}$ solution, $70 \%$ FA mixes containing $0 \%, 10 \%$ and $30 \%$ vermiculite had $5 \%, 11 \%$ and $31 \%$ lower ultrasound velocities, respectively, and for the 15 molar $\mathrm{NaOH}$ solution, they had $8 \%, 15 \%$ and $24 \%$ lower ultrasound velocities than the companion $50 \%$ FA mixes, respectively.

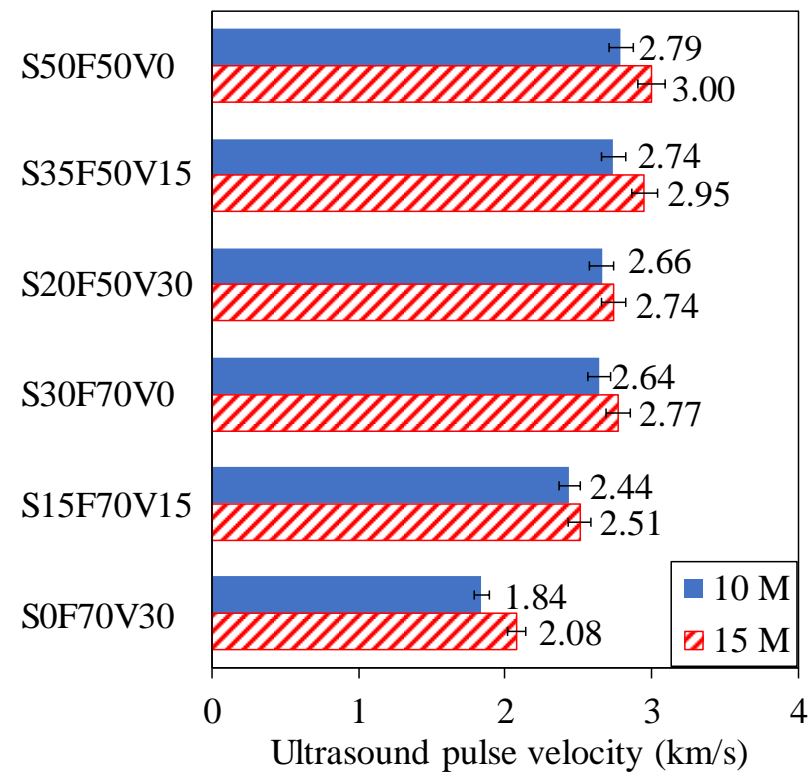

Figure 10. Ultrasound pulse velocities of the geopolymer mortar.

As can be observed from Figure 10, for a given FA content and $\mathrm{NaOH}$ concentration, the replacement of natural sand with expanded vermiculite caused a decrease in the ultrasound pulse velocities of the mixes. It is also observed that increased vermiculite contents resulted in decreased ultrasound velocities in the mixes. These findings are consistent with previous studies on conventional mortar $[9,26]$ and polyurethane foam composite [20], and they are attributed to the porous structure of expanded vermiculite, resulting in decreased propagation velocities of the ultrasonic pulses in mixtures containing expanded vermiculite [26]. At 50\% FA, the mixes containing $15 \%$ and $30 \%$ vermiculite had approximately $2 \%$ and $7 \%$ lower ultrasound velocities, respectively, and at $70 \% \mathrm{FA}$, they had approximately $9 \%$ and $28 \%$ lower ultrasound velocities in comparison with the companion mixes without vermiculite, respectively. As was reported previously, the ultrasound pulse velocity has a direct relationship with the compressive strength of concrete and mortar [26]; a decreased compressive strength leads to a decrease in the ultrasound pulse velocity. This trend is obvious in this study, showing that increasing the vermiculite 
content caused a decrease in strength, which consequently caused a decreased ultrasound pulse velocity in the geopolymer mortar.

\subsection{Thermal Conductivity}

The thermal conductivities of the different mixes are shown in Figure 11. It is shown in the figure that, for a given FA and vermiculite content, the mixes with the 10 molar $\mathrm{NaOH}$ solution developed lower thermal conductivities compared with those with the 15 molar $\mathrm{NaOH}$ solution. The lower thermal conductivities of the mixes having lower concentrations of the activator agree with previous research on metakaolin-based geopolymer paste [75] and geopolymer with marble waste and zeolitic tuff [51], and this is because the mixes with lower activator concentrations have higher porosities, which consequently results in increased thermal insulations in comparison with those having higher concentrations of the activator [51]. The 10 molar $\mathrm{NaOH}$ mixes with $50 \%$ and $70 \%$ FA exhibited $1-4 \%$ and 4-8\% lower thermal conductivities compared with the 15 molar $\mathrm{NaOH}$ mixes, respectively. As is also observed in the figure, for a given vermiculite content and $\mathrm{NaOH}$ concentration, the mixes containing larger amounts of FA had lower thermal conductivities in comparison with those containing smaller amounts of FA. This agrees with previous studies on cement mortar [76], cement concrete [77], gypsum composite [78] and lightweight concrete [79], and this is due to the increase in the porosities of the mixes with increasing contents of FA, causing increased thermal insulations in the mixes [79]. For the 10 molar $\mathrm{NaOH}$ solution, the $70 \%$ FA mixes containing $0 \%, 10 \%$ and $30 \%$ vermiculite exhibited $27 \%, 36 \%$ and $36 \%$ less thermal conductivity, respectively, and for the 15 molar $\mathrm{NaOH}$ solution, they exhibited $23 \%, 34 \%$ and $34 \%$ less thermal conductivity in comparison with the companion $50 \%$ FA mixes, respectively.

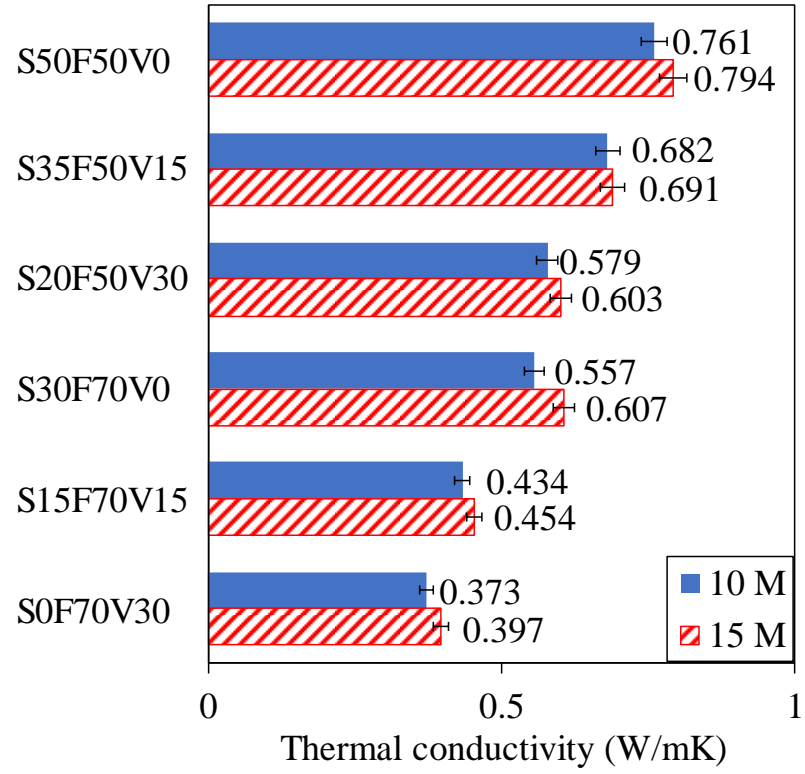

Figure 11. Thermal conductivities of the geopolymer mortar.

As can be seen in Figure 11, replacing the sand with expanded vermiculite led to a decrease in thermal conductivity in the mixes for a given FA content and $\mathrm{NaOH}$ concentration. It can also be seen from the figure that an increased amount of expanded vermiculite resulted in decreased thermal conductivities in the mixes. This behavior is similar with that found in previous research on conventional mortar [25,26], metakaolin-based geopolymer concrete [57], slag-based geopolymer mortar [65], gypsum composites [58] and clay-based bricks [59]. As was reported previously [80-82], the thermal conductivity has a direct relationship with the dry unit weight; a decreased dry unit weight leads to a decreased thermal conductivity. The same trend was observed in this study, showing that an increased vermiculite content caused a decreased unit weight, which consequently led to a decreased 
thermal conductivity of the geopolymer mortar. This is due to the lamellar structure of the expanded vermiculite, which contains large amount of air between the vermiculite flakes, helping to decrease the thermal insulation of the mixes [83]. At 50\% FA, the mixes containing $15 \%$ and $30 \%$ vermiculite exhibited approximately $12 \%$ and $24 \%$ lower thermal conductivities, and at $70 \% \mathrm{FA}$, they exhibited approximately $24 \%$ and $34 \%$ lower thermal conductivity than the companion mixes without vermiculite, respectively. As was reported by Demirboga and Kan [84], concrete mixes containing 100\% expanded polystyrene developed a thermal conductivity of $0.60 \mathrm{~W} / \mathrm{mK}$. However, the mortar mixes of the present study containing only $30 \%$ expanded vermiculite developed a similar or lower conductivity in comparison with the $100 \%$ expanded polystyrene mix of that study. It was also reported by Sengul et al. [21] that the thermal conductivity of the mortar mixes containing $40 \%$ expanded perlite was $0.53 \mathrm{~W} / \mathrm{mK}$, which was higher than the thermal conductivity of the $70 \%$ FA mixes in the present study containing 15\% expanded vermiculite. As was reported by Lach et al. [85], FA-based foamed geopolymer pastes containing 30\% microsphere, 70\% FA and $7 \%$ hydrogen peroxide as a foaming agent had a thermal conductivity of 0.095 $\mathrm{W} / \mathrm{mK}$ and a 28 day compressive strength of $1.9 \mathrm{MPa}$, which are lower than those found in the present study.

\section{Conclusions}

This paper has presented the first study on the properties of geopolymers containing expanded vermiculite as a sand material. The following conclusions can be made from presented results:

- At a given FA and expanded vermiculite content, geopolymers prepared with a 10 molar $\mathrm{NaOH}$ solution developed a higher flowability (6-14\%), apparent porosity $(2-10 \%)$ and water absorption (4-25\%), as well as a lower dry unit weight (4-14\%), compressive strength (13-22\%), ultrasound pulse velocity (3-11\%) and thermal conductivity (1-8\%) in comparison with those having a 15 molar $\mathrm{NaOH}$ solution. This observation was due to the more compact microstructures of the geopolymers with the 15 molar $\mathrm{NaOH}$ solution than those with the 10 molar $\mathrm{NaOH}$ solution;

- Geopolymers with a higher FA content exhibit a higher flowability, water absorption and apparent porosity, but a lower dry unit weight, compressive strength, ultrasound pulse velocity and thermal conductivity in comparison with those having a lower FA content for the same content of expanded vermiculite and $\mathrm{NaOH}$ concentration;

- For the same FA content and $\mathrm{NaOH}$ concentration, incorporating expanded vermiculite $(15 \%)$ resulted in a decrease in the flowability $(\sim 6 \%)$, dry unit weight $(\sim 6 \%)$, compressive strength $(\sim 7 \%)$, ultrasound pulse velocity $(\sim 6 \%)$ and thermal conductivity $(\sim 18 \%)$, as well as increased water absorption $(\sim 9 \%)$ and apparent porosity $(\sim 6 \%)$ in the geopolymer. This is due to the porous structure of the expanded vermiculite;

- An increase in the content of expanded vermiculite (from $15 \%$ to $30 \%$ ) resulted in a decrease in the flowability $(\sim 4 \%)$, dry unit weight $(\sim 5 \%)$, compressive strength $(\sim 9 \%)$, ultrasound pulse velocity $(\sim 13 \%)$ and thermal conductivity $(\sim 14 \%)$, as well as increased water absorption $(\sim 15 \%)$ and apparent porosity $(\sim 7 \%)$ in the geopolymer for a given FA content and $\mathrm{NaOH}$ concentration;

- The geopolymers prepared in this study containing 30\% expanded vermiculite exhibited a lower dry unit weight compared with those prepared in previous studies $[15,24]$ containing 30\% clay, pumice and expanded vermiculite. In addition, the geopolymer prepared with 30\% expanded vermiculite developed a lower thermal conductivity than the concrete with $100 \%$ expanded polystyrene [80] and cement mortar with $40 \%$ expanded perlite [14] prepared in previous studies. These results indicate great potential for producing an eco-friendly and lightweight building material with excellent sound and thermal characteristics. 
Author Contributions: Conceptualization, O.G.; methodology, O.G. and H.T.; validation, O.G., A.G., H.T. and T.O.; formal analysis, A.G.; investigation, O.G. and H.T.; writing—original draft preparation, A.G.; writing-review and editing, O.G., A.G. and T.O.; supervision, T.O. All authors have read and agreed to the published version of the manuscript.

Funding: This research received no external funding.

Institutional Review Board Statement: Not applicable.

Informed Consent Statement: Not applicable.

Data Availability Statement: Not applicable.

Conflicts of Interest: The authors declare no conflict of interest.

\section{References}

1. Farinha, C.B.; de Brito, J.; Veiga, R. Influence of forest biomass bottom ashes on the fresh, water and mechanical behaviour of cement-based mortars. Resour. Conserv. Recycl. 2019, 149, 750-759. [CrossRef]

2. Teh, S.H.; Wiedmann, T.; Castel, A.; de Burgh, J. Hybrid life cycle assessment of greenhouse gas emissions from cement, concrete and geopolymer concrete in Australia. J. Clean. Prod. 2017, 152, 312-320. [CrossRef]

3. Mehta, P.K.; Monteiro, P.J.M. Concrete Microstructure, Properties and Materials; McGraw Hill Professional: New York, NY, USA, 2017

4. Bravard, J.-P.; Goichot, M.; Gaillot, S. Geography of sand and gravel mining in the Lower Mekong River. First survey and impact assessment. EchoGéo 2013, 26, 1-20.

5. Shubbar, A.A.; Sadique, M.; Shanbara, H.K.; Hashim, K. The Development of a New Low Carbon Binder for Construction as an Alternative to Cement. In Advances in Sustainable Construction Materials and Geotechnical Engineering; Springer: Berlin/Heidelberg, Germany, 2020; pp. 205-213.

6. Hajimohammadi, A.; Ngo, T.; Vongsvivut, J. Interfacial chemistry of a fly ash geopolymer and aggregates. J. Clean. Prod. 2019, 231, 980-989. [CrossRef]

7. Blissett, R.S.; Rowson, N.A. A review of the multi-component utilisation of coal fly ash. Fuel 2012, 97, 1-23. [CrossRef]

8. Gowda, S.P.; Latha, M. Environmental concrete-Geopolymer of construction. Int. J. Curr. Res. 2017, 9, 62358-62360.

9. Köksal, F.; Serrano-López, M.A.; Şahin, M.; Gencel, O.; López-Colina, C. Combined effect of steel fibre and expanded vermiculite on properties of lightweight mortar at elevated temperatures. Mater. Struct. 2015, 48, 2083-2092. [CrossRef]

10. Indian Minerals Yearbook. Indian Minerals Yearbook 2018, Part-III: Mineral Reviews; Government of India, Ministry of Mines: Nagpur, India, 2019; Volume 27.

11. Melo, M.O.B.C.; da Silva, L.B.; Coutinho, A.S.; Sousa, V.; Perazzo, N. Energy efficiency in building installations using thermal insulating materials in Northeast Brazil. Energy Build. 2012, 47, 35-43. [CrossRef]

12. Schackow, A.; Effting, C.; Folgueras, M.V.; Güths, S.; Mendes, G.A. Mechanical and thermal properties of lightweight concretes with vermiculite and EPS using air-entraining agent. Constr. Build. Mater. 2014, 57, 190-197. [CrossRef]

13. Koksal, F.; Sahin, Y.; Gencel, O. Influence of expanded vermiculite powder and silica fume on properties of foam concretes. Constr. Build. Mater. 2020, 257, 119547. [CrossRef]

14. EPA-11.28. AP-42: Compilation of Air Emissions Factors, 11.28 Vermiculite Processing, 5th ed.; United States Environmental Protection Agency: Research Triangle Park, NC, USA, 1995; Volume 1, p. 11.

15. Onwudili, J.A.; Williams, P.T. Role of sodium hydroxide in the production of hydrogen gas from the hydrothermal gasification of biomass. Int. J. Hydrog. Energy 2009, 34, 5645-5656. [CrossRef]

16. Haneke, K.E. Review of Toxicological Literature; North Carolina, National Institute of Environmental Health Sciences: Durham, NC, USA, 2002; pp. 1-53.

17. Abidi, S.; Nait-Ali, B.; Joliff, Y.; Favotto, C. Impact of perlite, vermiculite and cement on the thermal conductivity of a plaster composite material: Experimental and numerical approaches. Compos. Part B Eng. 2015, 68, 392-400. [CrossRef]

18. Demirboğa, R.; Gül, R. The effects of expanded perlite aggregate, silica fume and fly ash on the thermal conductivity of lightweight concrete. Cem. Concr. Res. 2003, 33, 723-727. [CrossRef]

19. Hossain, K.M.A.; Ahmed, S.; Lachemi, M. Lightweight concrete incorporating pumice based blended cement and aggregate: Mechanical and durability characteristics. Constr. Build. Mater. 2011, 25, 1186-1195. [CrossRef]

20. Li, T.-T.; Chuang, Y.-C.; Huang, C.-H.; Lou, C.-W.; Lin, J.-H. Applying vermiculite and perlite fillers to sound-absorbing/thermalinsulating resilient PU foam composites. Fibers Polym. 2015, 16, 691-698. [CrossRef]

21. Sengul, O.; Azizi, S.; Karaosmanoglu, F.; Tasdemir, M.A. Effect of expanded perlite on the mechanical properties and thermal conductivity of lightweight concrete. Energy Build. 2011, 43, 671-676. [CrossRef]

22. Benli, A.; Karatas, M.; Toprak, H.A. Mechanical characteristics of self-compacting mortars with raw and expanded vermiculite as partial cement replacement at elevated temperatures. Constr. Build. Mater. 2020, 239, 117895. [CrossRef]

23. Chandra Sekar, G.; Manikanta, V.; Simhachalam, M. Effect of fly ash on mechanical properties of light weight vermiculite concrete. Int. J. Innov. Res. Sci. Eng. Technol. 2016, 5, 4106-4112. 
24. Karatas, M.; Benli, A.; Toprak, H.A. Effect of incorporation of raw vermiculite as partial sand replacement on the properties of self-compacting mortars at elevated temperature. Constr. Build. Mater. 2019, 221,163-176. [CrossRef]

25. Koksal, F.; del Coz Diaz, J.J.; Gencel, O.; Alvarez Rabanal, F.P. Experimental and numerical analysis of new bricks made up of polymer modified-cement using expanded vermiculite. Comput. Concr. 2013, 12, 19-36. [CrossRef]

26. Koksal, F.; Gencel, O.; Kaya, M. Combined effect of silica fume and expanded vermiculite on properties of lightweight mortars at ambient and elevated temperatures. Constr. Build. Mater. 2015, 88, 175-187. [CrossRef]

27. Mladenovič, A.; Šuput, J.S.; Ducman, V.; Škapin, A.S. Alkali-Silica reactivity of some frequently used lightweight aggregates. Cem. Concr. Res. 2004, 34, 1809-1816. [CrossRef]

28. Mo, K.H.; Lee, H.J.; Liu, M.Y.J.; Ling, T.-C. Incorporation of expanded vermiculite lightweight aggregate in cement mortar. Constr. Build. Mater. 2018, 179, 302-306. [CrossRef]

29. Sastri, M.; Kumar, P.A.; Rao, K.J. Experimental investigation on strength properties of ultrafine fly ash and micro silica as mineral admixtures for vermiculite mortar. I Manag. J. Mater. Sci. 2019, 7, 53. [CrossRef]

30. Shoukry, H.; Kotkata, M.F.; Abo-El-Enein, S.A.; Morsy, M.S.; Shebl, S.S. Enhanced physical, mechanical and microstructural properties of lightweight vermiculite cement composites modified with nano metakaolin. Constr. Build. Mater. 2016, 112, 276-283. [CrossRef]

31. Won, J.-P.; Kang, H.-B.; Lee, S.-J.; Lee, S.-W.; Kang, J.-W. Thermal characteristics of high-strength polymer-Cement composites with lightweight aggregates and polypropylene fiber. Constr. Build. Mater. 2011, 25, 3810-3819. [CrossRef]

32. BS-EN-1015-3. Methods of Test for Mortar for Masonry_Part 3: Determination of Consistence of Fresh Mortar (by Flow Table); British Standards Institution: London, UK, 1999.

33. ASTM-C20. Standard Test methods For Apparent Porosity, Water Absorption, Apparent Specific Gravity, and Bulk Density of Burned Refractory Brick and Shapes by Boiling Water; ASTM International: West Conshohocken, PA, USA, 2015.

34. TS-EN-12390-3. Testing Hardened Concrete-Part 3: Compressive Strength of Test Specimens; Turkish Standards Institute: Ankara, Turkey, 2010.

35. TS-EN-12504-4. Testing Concrete_Part 4: Determination of Ultrasonic Pulse Velocity; T.S. Institution: Ankara, Turkey, 2004.

36. Sathonsaowaphak, A.; Chindaprasirt, P.; Pimraksa, K. Workability and strength of lignite bottom ash geopolymer mortar. J. Hazard. Mater. 2009, 168, 44-50. [CrossRef] [PubMed]

37. Aliabdo, A.A.; Abd Elmoaty, M.; Salem, H.A. Effect of water addition, plasticizer and alkaline solution constitution on fly ash based geopolymer concrete performance. Constr. Build. Mater. 2016, 121, 694-703. [CrossRef]

38. Ryu, G.S.; Lee, Y.B.; Koh, K.T.; Chung, Y.S. The mechanical properties of fly ash-based geopolymer concrete with alkaline activators. Constr. Build. Mater. 2013, 47, 409-418. [CrossRef]

39. Topark-Ngarm, P.; Chindaprasirt, P.; Sata, V. Setting time, strength, and bond of high-calcium fly ash geopolymer concrete. J. Mater. Civ. Eng. 2015, 27, 04014198. [CrossRef]

40. Gholampour, A.; Ho, V.D.; Ozbakkaloglu, T. Ambient-cured geopolymer mortars prepared with waste-based sands: Mechanical and durability-related properties and microstructure. Compos. Part B Eng. 2019, 160, 519-534. [CrossRef]

41. Gholampour, A.; Ozbakkaloglu, T.; Etemadi, E.; Vincent, T. Sustainable mortars containing fly ash, glass powder and blast-furnace and lead-smelter slag. Mag. Concr. Res. 2020, 72, 447-459. [CrossRef]

42. Gholampour, A.; Ozbakkaloglu, T.; Ngo, T.D. Development of a waste-based eco-friendly structural mortar without Portland cement and natural sand. Struct. Concr. 2020. [CrossRef]

43. Hou, P.-K.; Kawashima, S.; Wang, K.-J.; Corr, D.J.; Qian, J.-S.; Shah, S.P. Effects of colloidal nanosilica on rheological and mechanical properties of fly ash-Cement mortar. Cem. Concr. Compos. 2013, 35, 12-22. [CrossRef]

44. Supit, S.W.M.; Shaikh, F.U.A.; Sarker, P.K. Effect of ultrafine fly ash on mechanical properties of high volume fly ash mortar. Constr. Build. Mater. 2014, 51, 278-286. [CrossRef]

45. Bingöl, A.F.; Tohumcu, İ. Effects of different curing regimes on the compressive strength properties of self compacting concrete incorporating fly ash and silica fume. Mater. Des. 2013, 51, 12-18. [CrossRef]

46. Şahmaran, M.; Yaman, İ.Ö.; Tokyay, M. Transport and mechanical properties of self consolidating concrete with high volume fly ash. Cem. Concr. Compos. 2009, 31, 99-106. [CrossRef]

47. Gholampour, A.; Ozbakkaloglu, T.; Ng, C.-T. Ambient- and oven-cured geopolymer concretes under active confinement. Constr. Build. Mater. 2019, 228, 116722. [CrossRef]

48. Şahmaran, M.; Yaman, Ö.; Tokyay, M. Development of high-volume low-lime and high-lime fly-ash-incorporated selfconsolidating concrete. Mag. Concr. Res. 2007, 59, 97-106. [CrossRef]

49. Sun, W.; Yan, H.; Zhan, B. Analysis of mechanism on water-reducing effect of fine ground slag, high-calcium fly ash, and low-calcium fly ash. Cem. Concr. Res. 2003, 33, 1119-1125. [CrossRef]

50. Görhan, G.; Kürklü, G. The influence of the $\mathrm{NaOH}$ solution on the properties of the fly ash-based geopolymer mortar cured at different temperatures. Compos. Part B 2014, 58, 371-377. [CrossRef]

51. Tekin, I.; Gencel, O.; Gholampour, A.; Oren, O.H.; Koksal, F.; Ozbakkaloglu, T. Recycling zeolitic tuff and marble waste in the production of eco-friendly geopolymer concretes. J. Clean. Prod. 2020, 268, 122298. [CrossRef]

52. Uygunoğlu, T.; Topcu, I.B.; Gencel, O.; Brostow, W. The effect of fly ash content and types of aggregates on the properties of pre-fabricated concrete interlocking blocks (PCIBs). Constr. Build. Mater. 2012, 30, 180-187. [CrossRef] 
53. Fu, X.; Wang, Z.; Tao, W.; Yang, C.; Hou, W.; Dong, Y.; Wu, X. Studies on blended cement with a large amount of fly ash. Cem. Concr. Res. 2002, 32, 1153-1159. [CrossRef]

54. Garg, M.; Pundir, A. Comprehensive study of fly ash binder developed with fly ash-Alpha gypsum plaster-Portland cement. Constr. Build. Mater. 2012, 37, 758-765. [CrossRef]

55. Jiang, F.; Zhang, L.; Mukiza, E.; Qi, Z.; Cang, D. Formation mechanism of high apparent porosity ceramics prepared from fly ash cenosphere. J. Alloy. Compd. 2018, 749, 750-757. [CrossRef]

56. Qian, H.; Cheng, X.; Zhang, H.; Zhang, R.; Wang, Y. Preparation of porous mullite ceramics using fly ash cenosphere as a pore-forming agent by gelcasting process. Int. J. Appl. Ceram. Technol. 2014, 11, 858-863. [CrossRef]

57. Medri, V.; Papa, E.; Mazzocchi, M.; Laghi, L.; Morganti, M.; Francisconi, J.; Landi, E. Production and characterization of lightweight vermiculite/geopolymer-based panels. Mater. Des. 2015, 85, 266-274. [CrossRef]

58. Gencel, O.; del Coz Diaz, J.J.; Sutcu, M.; Koksal, F.; Rabanal, F.P.A.; Martinez-Barrera, G.; Brostow, W. Properties of gypsum composites containing vermiculite and polypropylene fibers: Numerical and experimental results. Energy Build. 2014, 70, 135-144. [CrossRef]

59. Sutcu, M. Influence of expanded vermiculite on physical properties and thermal conductivity of clay bricks. Ceram. Int. 2015, 41, 2819-2827. [CrossRef]

60. Sata, V.; Wongsa, A.; Chindaprasirt, P. Properties of pervious geopolymer concrete using recycled aggregates. Constr. Build. Mater. 2013, 42, 33-39. [CrossRef]

61. Tekin, I. Properties of $\mathrm{NaOH}$ activated geopolymer with marble, travertine and volcanic tuff wastes. Constr. Build. Mater. 2016, 127, 607-617. [CrossRef]

62. Gunasekaran, M.M.; Priyalakshmi, A.; Anudevi, C.; Premachandar, H.; Balamuruagn, V. Study on vermiculite incorporate in mortar. Int. J. Innov. Res. Sci. Technol. 2016, 2, 36-42.

63. Al-Jabri, K.S.; Hago, A.W.; Taha, R.; Alnuaimi, A.S.; Al-Saidy, A.H. Strength and insulating properties of building blocks made from waste materials. J. Mater. Civ. Eng. 2009, 21, 191-197. [CrossRef]

64. Rahman, S.S.A.; Babu, G.K. An experimental investigation on light weight cement concrete using vermiculite minerals. Int. J. Innov. Res. Sci. Eng. Technol. 2016, 5, 2389-2392.

65. Boháčová, J.; Vavro, M.; Staněk, S. Properties of thermal insulating alkali activated system research and development. Trans. VŠB Tech. Univ. Ostrav. Civ. Eng. Ser. 2011, 11, 1-10. [CrossRef]

66. Martias, C.; Joliff, Y.; Favotto, C. Effects of the addition of glass fibers, mica and vermiculite on the mechanical properties of a gypsum-based composite at room temperature and during a fire test. Compos. Part B Eng. 2014, 62, 37-53. [CrossRef]

67. Mishra, A.; Choudhary, D.; Jain, N.; Kumar, M.; Sharda, N.; Dutt, D. Effect of concentration of alkaline liquid and curing time on strength and water absorption of geopolymer concrete. ARPN J. Eng. Appl. Sci. 2008, 3, 14-18.

68. Huseien, G.F.; Mirza, J.; Ismail, M.; Hussin, M.W.; Arrifin, M.A.M.; Hussein, A.A. The effect of sodium hydroxide molarity and other parameters on water absorption of geopolymer mortars. Indian J. Sci. Technol. 2016, 9, 1-7. [CrossRef]

69. Kumar, S. A perspective study on fly ash-Lime-Gypsum bricks and hollow blocks for low cost housing development. Constr. Build. Mater. 2002, 16, 519-525. [CrossRef]

70. Kim, Y.Y.; Lee, B.-J.; Saraswathy, V.; Kwon, S.-J. Strength and durability performance of alkali-activated rice husk ash geopolymer mortar. Sci. World J. 2014, 2014, 209584. [CrossRef] [PubMed]

71. Li, G.; Zhao, X. Properties of concrete incorporating fly ash and ground granulated blast-furnace slag. Cem. Concr. Compos. 2003, 25, 293-299. [CrossRef]

72. EN-13279-1. Gypsum Binders and Gypsum Plasters: Part 1: Definitions and Requirements; European Committee for Standardization: Brüssels, Belgium, 2008.

73. Boğa, A.R.; Topçu, I.B. Influence of fly ash on corrosion resistance and chloride ion permeability of concrete. Constr. Build. Mater. 2012, 31, 258-264. [CrossRef]

74. Demirboğa, R.; Türkmen, İ.; Karakoc, M.B. Relationship between ultrasonic velocity and compressive strength for high-volume mineral-admixtured concrete. Cem. Concr. Res. 2004, 34, 2329-2336. [CrossRef]

75. Jaya, N.A.; Yun-Ming, L.; Abdullah, M.M.A.B.; Cheng-Yong, H.; Hussin, K. Effect of Sodium Hydroxide Molarity on Physical, Mechanical and Thermal Conductivity of Metakaolin Geopolymers. IOP Conf. Ser. Mater. Sci. Eng. 2017, 343, 012015. [CrossRef]

76. Chen, M.; Wang, S.; Lu, L.; Zhao, P.; Gong, C. Effect of matrix components with low thermal conductivity and density on performances of cement-EPS/VM insulation mortar. J. Therm. Anal. Calorim. 2016, 126, 1123-1132. [CrossRef]

77. Demirboğa, R. Thermal conductivity and compressive strength of concrete incorporation with mineral admixtures. Build. Environ. 2007, 42, 2467-2471. [CrossRef]

78. Joshi, R.C.; Thomas, J.O.; Adam, R.B. Properties of gypsum wallboards containing fly ash. J. Mater. Civ. Eng. 1992, 4, $212-225$. [CrossRef]

79. Demirboğa, R.; Gül, R. Thermal conductivity and compressive strength of expanded perlite aggregate concrete with mineral admixtures. Energy Build. 2003, 35, 1155-1159. [CrossRef]

80. Kim, K.-H.; Jeon, S.-E.; Kim, J.-K.; Yang, S. An experimental study on thermal conductivity of concrete. Cem. Concr. Res. 2003, 33, 363-371. [CrossRef]

81. Liu, M.Y.J.; Alengaram, U.J.; Jumaat, M.Z.; Mo, K.H. Evaluation of thermal conductivity, mechanical and transport properties of lightweight aggregate foamed geopolymer concrete. Energy Build. 2014, 72, 238-245. [CrossRef] 
82. Zhang, B.; Poon, C.S. Use of furnace bottom ash for producing lightweight aggregate concrete with thermal insulation properties. J. Clean. Prod. 2015, 99, 94-100. [CrossRef]

83. Rashad, A.M. Vermiculite as a construction material-A short guide for civil engineer. Constr. Build. Mater. 2016, 125, 53-62. [CrossRef]

84. Demirboga, R.; Kan, A. Thermal conductivity and shrinkage properties of modified waste polystyrene aggregate concretes. Constr. Build. Mater. 2012, 35, 730-734. [CrossRef]

85. Łach, M.; Korniejenko, K.; Mikuła, J. Thermal insulation and thermally resistant materials made of geopolymer foams. Procedia Eng. 2016, 151, 410-416. [CrossRef] 